\title{
Long-term changes on coral reefs in booming populations of a competitive colonial ascidian
}

\author{
R. P. M. Bak ${ }^{1,2, \bullet}$, D. Y. M. Lambrechts ${ }^{1,2}$, M. Joenje ${ }^{1,2}$, G. Nieuwland ${ }^{1}$, M. L. J. Van Veghel ${ }^{2}$ \\ ${ }^{1}$ Netherlands Institute for Sea Research (NIOZ), PO Box 59, 1790 AB Den Burg, The Netherlands \\ ${ }^{2}$ Institute of Systematics and Population Biology, PO Box 94766 , University of Amsterdam, 1090 GT Amsterdam, The Netherlands
}

\begin{abstract}
A long-term study of the common coral reef spatial competitor Trididemnum solidum (van Name), a benthic colonial ascidian, showed a $900 \%$ increase in densities along the $84 \mathrm{~km}$ of fringing reef in Curaçao over $15 \mathrm{yr}$. The pattern of distribution along the coast did not change significantly and showed long-term effects of philopatry. This pattern relates to limited dispersal potential and the impact of the clonal ecological strategy of this modular organism. All hard reef substrata were overgrown but between 1978 and 1993 there was a significant increase in the number of ascidian colonies overgrowing dominant scleractinian corals such as Montastrea annularis.
\end{abstract}

KEY WORDS: Coral reef $\cdot$ Ascidian $\cdot$ Competition $\cdot$ Long-term change

Long-term records of population dynamics of benthic organisms are urgently needed to interprete changes in the marine environment. Such data are available to some degree for the temperate zones (e.g. Dörjes et al. 1987, Beukema 1989) but are very rare for tropical systems such as coral reefs. Most coral reefs are coastal systems and as such are subjected to all environmental changes connected with human population explosions along tropical coastlines (Buddemeier 1993, Wilkinson 1993). The few long-term data available for reefs are virtually restricted to scleractinian corals (e.g. Bak \& Luckhurst 1980, Dollar \& Tribble 1993, Hughes 1994, Bak \& Nieuwland 1995). We report here on our observations over a 15 yr period on density and distribution of a compound ascidian Trididemnum solidum (van Name) over the $84 \mathrm{~km}$ fringing reef along the leeward coast of Curaçao (Netherlands Antilles). $T$. solidum is a colonial substratum-encrusting organism with a diameter of up to $30 \mathrm{~cm}$. It is a highly mobile

\footnotetext{
•E-mail: rbak@nioz.nl.
}

competitor for space on hard substratum, a possibly limited resource on coral reefs. It grows up to $10 \mathrm{~cm}$ $\mathrm{mo}^{-1}$ and shows a very flexible pattern of fission and fusion of colonies (Bak et al. 1981).

We studied aspects of the ecology of Trididemnum solidum, including the distribution along the coasts of the island in Curaçao in 1978. Since then, annual photographic records (Bak \& Nieuwland 1995) and other observations have suggested a steady increase in densities and competitive impact of the ascidian over the years. The 3 questions we posed in 1993 were as follows: (1) has there been an increase in population density; (2) has there been a change in distribution pattern; and (3) has there been an increase in interactions with other benthic invertebrates?

To facilitate a comparison with the 1978 density and distribution data we employed the same survey method at the same localities in 1993. We recorded numbers of genets (clusters of separate colonies attached to the same area of substratum) and ramets (separate colonies) in $5 \mathrm{~m}$ wide belt transects running from 1.5 to $35 \mathrm{~m}$ depth perpendicular to the shore over the reef bottom. Such a definition of a genet is obviously only a minimum approximation of total genet number in the populations, but such data will reflect some of the dynamics of the fusion/fission processes. Type of substratum, such as rock with algal turf, crustose corallines, coral species or sponge, was recorded for each ascidian colony. A total of 42 sites was examined from west to east along the leeward coast of the island (Fig 1).

We found an enormous increase (Fig. 1) in the abundance of colonies in 1993 (paired samples t-test log transformed data, $t=5.909, \mathrm{p}<0.001)$. The overall number of colonies increased $900 \%$ (from 916 to 8272 colonies in the transects). Densities over the reef bottom increased all along the coast about 2 orders of 


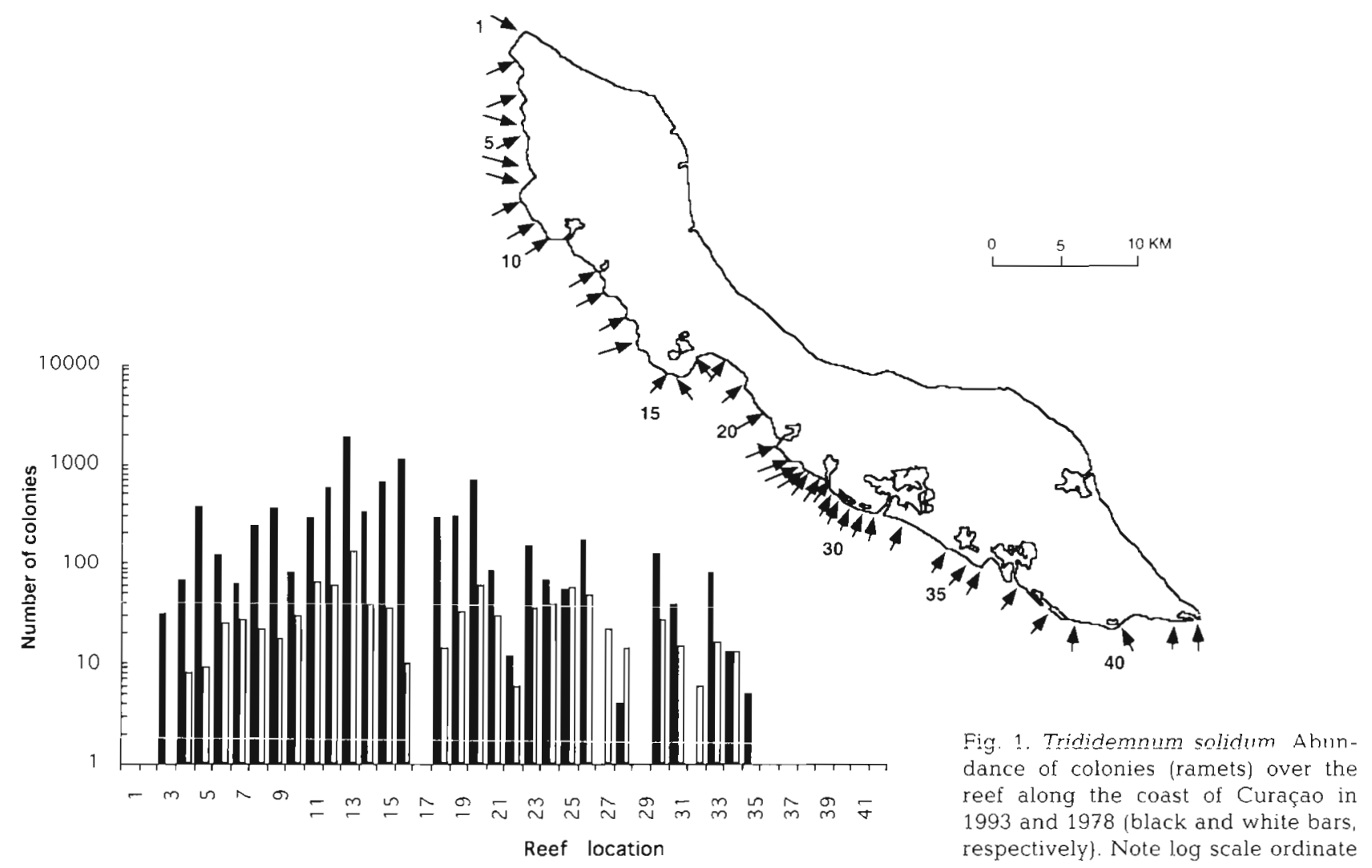

magnitude (Fig. 2). This increase in ramet densities was paralleled in the number of genets, and the significant linear relation between ramet/genet numbers did not differ between the years (regression: $r^{2}=0.986$; ANOVA: $F 1,53=3.22, \mathrm{p}=0.079$ ).

The pattern of distribution along the coast did not change significantly (paired samples $t$-test, logit transformed data, $p=0.062$ ). The population spread a few hundred meters, or one transect site, to the east and the west (Fig. 1). The ascidians occur as a virtually uninterrupted population along the coast, absent only from some rubble slopes (Locations 17 and 27) and sites of extreme pollution such as down current of the island power plant and the mouth of the harbour

The ascidians practically do not occur on loose substrata such as coral rubble and sand. Coral rock with thin algal turfs is their preferred substratum. In 1978 , $43 \%$ of all colonies occurred on rock, the remainder on living corals and other sessile animals. The much higher population density in 1993 resulted in a much higher occurrence of the ascidian on all available substrata but the absolute increase in number of colonies
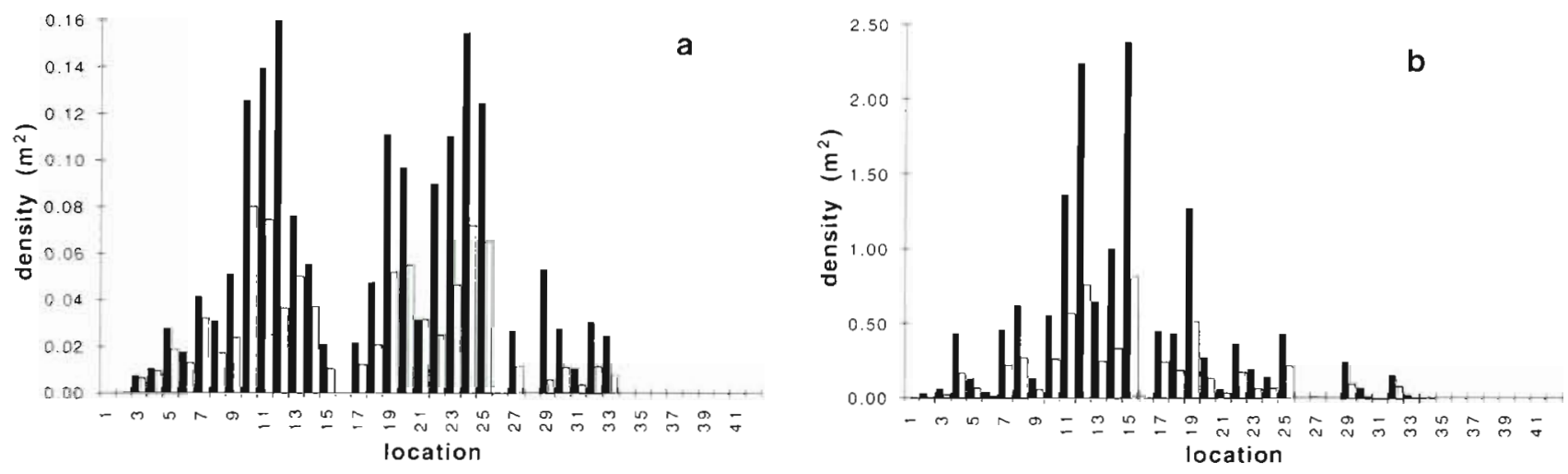

Fig. 2. Trididemnum solidum. Pattern and density of ramets and genets along the coast in (a) 1978 and (b) 1993. Black bars show ramet densities; white bars show genet densities. Note different ordinate scales 


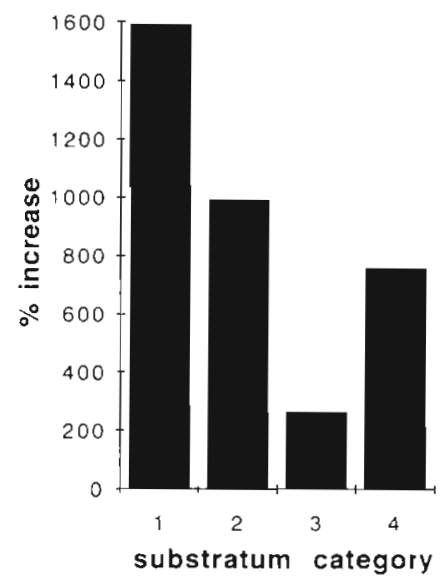

Fig. 3. Tridıdemnum solidum. Percentage increase in number of colonies of over different hard substratum types. (1) Dominant corals; (2) other corals; (3) other organisms; (4) coral rock and thin turf algae

was different for the different substratum categories $(G=633.4, \mathrm{df}=19, \mathrm{p}<0.001)$. The greatest increase in overgrowth was over the most common scleractinian Corals (Fig. 3), with $45 \%$ of the colonies growing over Agaricia agaricites, Eusmilia fastigiata and Montastrea annularis (all 3 morphotypes) (Knowlton et al. 1992, Van Veghel \& Bak 1993).

Apparently, the answers to our 3 research questions are as follows: (1) yes, there has been a tremendous increase in ascidian density; (2) the distribution shows no marked changes in pattern but the ascidian has spread a few hundred meters along the coast; and (3) yes, there is increased competition for space, in particular, with the most common coral species.

Life history traits such as the very short pelagic freeswimming period of the tadpole larvae, resulting in settlement in the vicinity of the parent colony (van Duyl et al. 1981), explain the limited spread of the population along the coast during the past $15 \mathrm{yr}$. The increase in ascidian density is caused by increased settlement of larvae, resulting in new colonies which subsequently undergo fission. It is not caused by increased fission of extant colonies, which would have resulted in a change in the ramet/genet ratio. Trididemnum solidum apparently competes very successfully with other sessile organisms for the available resources such as space and food. New space for settlement is frequently produced by small scale events (Bak \& Luckhurst 1980), and ascidian tadpole larvae, produced daily throughout the year (van Duyl et al. 1981), are successful in such a. habitat. Competition for space is facilitated by the fast growth rates, up to $14 \mathrm{~cm}$ linear growth per month, and the high rates of fission and fusion of colonies (Bak et al. 1981). $T$ solidum is phototrophic as well as filter-feeding (Sybesma et al. 1981,
Olson 1986), ingesting small bacteria (Bak, Joenje, Lambrechts unpubl.) and is well adapted to taking advantage of high bacterial densities, with up to $2 \times 10^{6}$ cells $\mathrm{ml}^{-1}$ (Bak \& Nieuwland unpubl) recently occurring along the coast. It is tempting to speculate that increased human activity results in a marine environment less favourable to corals, in which the ascidian would have a competitive advantage.

Recent reports suggest widespread degradation of coral reefs (Ginsburg \& Glynn 1994). The events reported in the literature are major disturbances and spectacular disruptions of the state of the health of coral populations such as bleachings and large-scale mortality. Our report on change in densities of a very competitive coral reef benthic invertebrate highlights another kind of disturbance or non-equilibrium. Such change, though representing an enormous increase in the density of an ahermatype in hermatypic communities, is less conspicuous to the student of change in reefs and only obvious in the long-term perspective.

Acknowledgements. We thank the staff of Carmabi Curaçao for cooperation and hospitality, the Foundation Reef Care Curaçao for enthusiastic support and E. M. Meesters and $\mathrm{J}$. van der Mrer for assistance and advice. This is NIOZ publication no. 3056 .

\section{LITERATURE CITED}

Bak RPM, Luckhurst E (1980) Constancy and change in coral reef habitats along depth gradients at Curaçao. Oecologia 47:145-155

Bak RPM, Nieuwland G (1995) Long-term change in coral communities along depth gradients over leeward reefs in the Netherlands Antilles. Bull Mar Sci 56:609-619

Bak RPM, Sybesma J, van Duyl FC (1981) The ecology of the tropical compound ascidian Trididemnum solidum. II. Abundance, growth and survival. Mar Ecol Prog Ser 6: $43-52$

Beukema JJ (1989) Long-term changes in macrozoobenthic abundance on the tidal flats of the western part of the Dutch Wadden Sea. Helgoländer Meeresunters 43: 405-415

Buddemeier RW (1993) Corals, climate and conservation. Proc 7 th Int Symp Coral Reefs 1:3-10

Dollar SJ. Tribble GW (1993) Recurrent storm disturbance and recovery: a long-term study of coral reef communities in Hawan. Coral Reefs 12:223-233

Dorjes J, Michaelis $H$, Rhode B (1987) Long-term studies of macrozoobenthos in intertidal and shallow subtidal habitats near the island of Norderney (East Frisian coast, Germany). Junk, Dordrecht

Ginsburg RN, Glynn PW (1994) Summary of the colloquium and forum on global aspects of coral reefs: health, hazards and history. In: Ginsburg RN (ed) Proceedings of the Colloquium and Forum on Global Aspects of Coral Reefs. RSMAS, University of Miami, Miami, p I-IX

Hughes TP (1994) Catastrophies, phase shifts, and large-scale degradation of a Caribbean coral reef. Science 265 $1547-1551$ 
Knowlton N, Weil E, Weight LA, Guzman HM (1992) Sibling species in Montastrea annularis, coral bleaching, and the coral cimate record. Science 255:330-333

Olson RR (1986) Photoadaptations of the Caribbean ascidiancyanophyte symbiosis Trdidemnum solidum. Biol Bull $170: 62-74$

Sybesma J, van Duyl FC, Bak RPM (1981) The ecology of the tropical compound ascidian Trididemnum solidum. III Symbiotic association with unicellular algae. Mar Ecol Prog Ser 6:53-59

van Duyl FC, Bak RPM, Sybesma J (1981) The ecology of the

This note was submitted to the editor tropical compound ascidian Trididemnum solidum. I Reproductive strategy and larval behaviour Mar Ecol Prog Ser 6:35-42

Van Veghel MLJ, Bak RPM (1993) Intraspecific variation of a dominant Caribbean reef coral Montastrea annularis genetic, behavioral and morphometric aspects. Mar Ecol Prog Ser 92:255-265

Wilkinson CR (1993) Coral reefs of the world are facing widespread devastation: can we prevent this through sustainable management practices? Proc 7th Int Symp Coral Reefs 1:11-21

Manuscript first received: December 12, 1995

Revised version accepted: January 23, 1996 